\title{
The Entry of D-Ribose into some Yeasts of the Genus Pichia
}

\author{
By J. A. BARNETT \\ School of Biological Sciences, University of East Anglia, \\ Norwich $N_{4}{ }_{7} T J$
}

(Received 9 April 1974; revised II April 1975)

\begin{abstract}
SUMMARY
The utilization of D-ribose by yeasts of the genus Pichia was examined with respect to aerobic growth, respiration and entry of ribose into the cells. Pichia etchellsii (CBS2O I I) could respire D-ribose, but not use it for aerobic growth. Pichia fermentans (CBSI87) neither respired nor grew on D-ribose, though it entered the cells of this yeast either by simple diffusion or, possibly, by the D-glucose carrier, this having a very low affinity for D-ribose. Pichia pinus (CBS5097) respired and grew on D-ribose; kinetic evidence is given for this yeast having two ribose carriers, one inducible and the other constitutive.
\end{abstract}

\section{INTRODUCTION}

It is remarkable that most yeasts which are able to use D-ribose as a sole source of carbon for aerobic growth can also grow aerobically on ribitol. However, the converse is not true. For example, of 495 strains of species of various genera, examined by N. J. W. Kreger-van Rij and D. Yarrow (cited by Barnett, 1975), none appeared to utilize D-ribose which did not also utilize ribitol: I45 strains were D-ribose + , ribitol + ; 233 were D-ribose - , ribitol - ; 117 were D-ribose - , ribitol + . This association of the ability of yeasts to utilize D-ribose and ribitol is consistent with the following hypotheses for yeasts in general: (i) the first step in the catabolism of D-ribose is its reduction to ribitol; (ii) D-ribose and ribitol are equally free to enter the cells across the plasmalemma; (iii) hence, they are equally accessible to the appropriate enzymes of catabolism.

To investigate the validity of these generalizations, a few yeasts were selected from each of three categories (Table 1 ): D-ribose-, ribitol + ; positive for both substrates; negative for both substrates. This paper records the first part of an investigation into the utilization of D-ribose by these selected yeasts, which all belong to species of the genus Pichia. The main question considered here is whether D-ribose enters yeasts that do not utilize it.

\section{METHODS}

Yeasts. These are listed in Table I.

Media. The following media were used: (i) Difco Bacto YM agar (pH 6.2); (ii) the chemically-defined carbon-free medium (N-base), $\mathrm{pH} 4 \cdot 8$, of Wickerham \& Burton (1948), without amino acids (Barnett $\&$ Ingram, I955), to which different organic compounds were added, each to a final concentration of $50 \mathrm{~mm}$.

Chemicals. Where possible, the chemicals were of analytical grade. Ribitol was recrystallized twice from ethanol, then twice from water by the addition of acetone. Commercial D-ribose was purified through its 'anilide' and recrystallized from ethanol (Whistler \& 
Table I. Aerobic growth of eight yeasts of the genus Pichia on D-ribose or ribitol

The yeasts were grown in T-tubes, using a recording nephelometer (Barnett, 1968 $b$ ), with $50 \mathrm{~mm}$ D-ribose, ribitol or D-glucose as sole source of carbon. Inoculation was from I-day-old slopes of YM agar. Results with D-glucose are given for comparison.

\begin{tabular}{|c|c|c|c|c|c|}
\hline \multirow[b]{2}{*}{ Pichia species } & \multicolumn{2}{|c|}{ Taxonomist's assessment* } & \multicolumn{3}{|c|}{$\begin{array}{l}\text { Specific growth rate } \\
\text { (generations } / \mathrm{h}) \dagger\end{array}$} \\
\hline & D-Ribose & Ribitol & D-Ribose & Ribitol & D-Glucose \\
\hline P. farinosa $\mathrm{CBSI} 85$ & +++ & +++ & 0.05 & $0 \cdot I$ & 0.3 \\
\hline P. robertsii $\ddagger$ CBS2934 & $++t$ & $+t+$ & 0.03 & 0.2 & 0.3 \\
\hline$P$. pinus CBS5097 & +++ & $+t+$ & 0.2 & 0.2 & 0.4 \\
\hline P. trehalophila CBS536r & $+t+$ & $+t+$ & 0.2 & 0.3 & 0.3 \\
\hline P. etchellsii CBS2OII & - & +++ & - & 0.3 & 0.4 \\
\hline P. vini $\mathrm{CBS} 4050$ & - & $++t$ & - & 0.07 & 0.2 \\
\hline P. polymorpha CBSI 86 & + & + & 0.1 & 0.2 & 0.3 \\
\hline P. fermentans CBS 187 & - & - & - & - & 0.3 \\
\hline
\end{tabular}

+++ , Strong growth; + , weak growth; - , no growth; CBS, Centraalbureau voor Schimmelcultures, Delft, The Netherlands.

* Results of Dr N. J. W. Kreger-van Rij (personal communication; for methods see Kreger-van Rij, I964).

$\dagger$ Mean results of duplicated experiments.

$\ddagger$ Now called Wingea robertsii (van der Walt, 1970).

Bemiller, 1962). The melting points of both ribitol and D-ribose were checked. D-[U- $\left.{ }^{14} \mathrm{C}\right]-$ glucose ( 2 to $4 \mathrm{mCi} / \mathrm{mmol}$ ) and $\mathrm{D}-\left[\mathrm{I}^{14} \mathrm{C}\right]$ ribose $(5$ to $10 \mathrm{mCi} / \mathrm{mmol})$ were obtained from The Radiochemical Centre, Amersham, Buckinghamshire; their specific activities and purities were not checked.

Rates of growth. For aerobic growth at $25{ }^{\circ} \mathrm{C}$, rocked T-tubes of $40 \mathrm{ml}$ total capacity, containing I $5 \mathrm{ml} \mathrm{N}$-base and a source of carbon, were used with a recording nephelometer, calibrated in terms of dry weight (Barnett, 1968b). Growth was measured hourly.

Dry weights. Yeast dry weights were measured as described by Barnett (I968b). Between 280 and $350 \mu \mathrm{g}$ dry wt $/ \mathrm{ml}$, the dry weight was proportional to the number of cells of $P$. pinus, as counted with a Model A Coulter counter (Coulter Electronic Corp., U.S.A.) $(300 \mu \mathrm{g} / \mathrm{ml}$ $\hat{=} 17 \times 10^{6}$ cells $/ \mathrm{ml}$ ).

Rates of respiration. Yeast from a I-day-old YM slope was used to inoculate $100 \mathrm{ml}$ of $\mathrm{N}$-base with an appropriate carbon source, in one or several Pyrex Fernbach culture flasks of $1000 \mathrm{ml}$ total capacity. The flasks were rocked at $\mathrm{I}$ cycle/s through an angle of about $6^{\circ}$ either side of horizontal for $20 \mathrm{~h}$ at $25^{\circ} \mathrm{C}$. The contents of each Fernbach flask were centrifuged and the yeast washed and resuspended in $50 \mathrm{ml}$ of $0 . \mathrm{I} M-\mathrm{KH}_{2} \mathrm{PO}_{4}$. To reduce the endogenous rate of oxygen uptake, the suspension was replaced in a clean Fernbach flask and starved for $3 \mathrm{~h}$ at $25^{\circ} \mathrm{C}$; it was then centrifuged and resuspended in $0 \cdot \mathrm{I} \mathrm{M}^{-} \mathrm{KH}_{2} \mathrm{PO}_{4}$ at a final concentration of about $2 \mathrm{mg}$ dry $\mathrm{wt} / \mathrm{ml}$. All yeast suspensions were checked visually by phase-contrast microscopy for microbial contamination. Oxygen uptake was measured with Warburg manometers, as described by Barnett (I968 b).

Rates of entry of D-ribose. The yeast suspensions were prepared as for the respiratory measurements, but starved for only $2 \mathrm{~h}$. The methods of measuring entry of D-ribose were based on those described by Kotyk \& Janáček (1970). Yeast suspension ( 5 to Io ml, depending on the number of samples to be taken) was incubated in a $25 \mathrm{ml}$ conical flask either at 25 or $30^{\circ} \mathrm{C}$ in a water bath, or in an ice and water mixture over an immersible magnetic stirrer (Rank Brothers, Bottisham, Cambridge) stirred vigorously with a small Tefloncovered magnet in the flask. 
Inhibitors, $5 \mu \mathrm{M}$-carbonyl cyanide $m$-chlorophenyl hydrazone (CCCP), or $25 \mu \mathrm{M}$ $\mathrm{UO}_{2}\left(\mathrm{NO}_{3}\right)_{2}$, when used, were added to the yeast suspension $10 \mathrm{~min}$ before zero time. The molarities given are the final concentrations used.

At zero time, $\mathrm{D}$-[I $\left.\mathrm{I}^{14} \mathrm{C}\right] \mathrm{ribose}$ (usually at about $\mathrm{I} \cdot 25 \mathrm{nCi} / \mu \mathrm{mol}$ ) was added. In certain experiments, ribitol, D-glucose or 2-deoxy-D-glucose were also added.

At timed intervals, usually every minute for Io min, samples of about $500 \mu \mathrm{l}$ (S.D. $\approx$ $\pm 2 \mu \mathrm{l}$ ) were taken with an Eppendorf piston pipette. Each sample was discharged immediately on to either a Millipore (DAWP 02500) cellulose ester membrane filter, $25 \mathrm{~mm}$ diameter, pore size $0.65 \mu \mathrm{m}$, or a Sartorius (SM I I305025) cellulose nitrate filter, pore size $0.6 \mu \mathrm{m}$. The filter was held in a chilled stainless steel holder (Kotyk \& Janáček, 1970) on a Buchner flask under reduced pressure. The yeast on the membrane was washed twice with I $\mathrm{ml}$ ice-cold water. Filtering and washing together took less than $20 \mathrm{~s}$. Each membrane was then transferred to a polyethylene vial and dried immediately in an oven at $80{ }^{\circ} \mathrm{C}$. To each vial and its contents, when cool, were added $15 \mathrm{ml}$ of toluene with $0.7 \%(\mathrm{w} / \mathrm{v})$ 2,5-diphenyloxazole.

Two adverse criticisms might be made of these techniques for measuring the uptake of D-ribose: entry into washed, starved, resting cells might differ greatly from that into exponentially-growing cells; since changes in radioactivity were measured solely on the yeast itself, kinetic analysis might be vitiated by changes in the proportion of ${ }^{14} \mathrm{C}$ remaining in the yeast as compared with that lost from it. To meet these criticisms, additional uptake experiments were done on cultures growing exponentially, and also the disappearance of radioactivity from the suspending medium was used as a further criterion of uptake.

An exponentially-growing yeast suspension ( $15 \mathrm{~h}$ ) was transferred to a flask equipped with a stirrer, in a water bath at $25^{\circ} \mathrm{C}$. Samples were taken from this flask at timed intervals for measuring growth spectrophotometrically. For each measurement of uptake, $10 \mathrm{ml}$ of the suspension were filtered with a Millipore URWP membrane of $25 \mathrm{~mm}$ diameter and $\mathrm{I} \cdot 5 \mu \mathrm{m}$ pore size. The yeast was washed on the membrane with $3.5 \mathrm{ml}$ of sugar-free $\mathrm{N}$-base medium at $25^{\circ} \mathrm{C}$. The washed yeast and the membrane filter carried with them about $40 \mu \mathrm{l}$ exogenous water. At zero time, a membrane filter and yeast were put into an experimental flask (50 ml Quickfit, B24 stopper) containing Io $\mathrm{ml}$ of N-base at $25^{\circ} \mathrm{C}$ to which $\mathrm{D}-\left[{ }^{14} \mathrm{C}\right]-$ ribose had been added. The yeast was dispersed into the medium by vigorous mechanical agitation for $15 \mathrm{~s}$, and a Teflon-covered magnetic stirrer put in the experimental flask which was stirred vigorously at $25^{\circ} \mathrm{C}$ in a water bath. Samples of about $1 \mathrm{ml}$ were taken, usually at $2 \mathrm{~min}$ intervals, for about I4 minutes. The samples were centrifuged with an Eppendorf Microcentrifuge 3200 at about $8000 \mathrm{~g}$ for about $30 \mathrm{~s}$, and $200 \mu \mathrm{l}($ S.D. $\approx \pm 2 \mu \mathrm{l}$ ) of the supernatant were added to $15 \mathrm{ml}$ of scintillation fluid $(7 \mathrm{~g}$ of 2,5-diphenyloxazole in 11 toluene and $500 \mathrm{ml}$ Triton X-100).

For measurements of loss from the suspending medium, it was only practicable to work with concentrations of from 0.2 to $3 \mathrm{~mm}$ D-ribose for a given amount of yeast (about $280 \mu \mathrm{g} \mathrm{dry} \mathrm{wt} / \mathrm{ml})$. With concentrations much below $0.2 \mathrm{mM}$, the rate of loss fell steadily after incubation for $3 \mathrm{~min}$ or less; above $3 \mathrm{mM}$, the errors of measurement were excessive because too small a proportion of D-ribose was lost from the medium.

In addition to the kinetic constants, the ratio of ${ }^{14} \mathrm{C}$ incorporated into the yeast (net uptake) to loss from the medium was measured for $P$. pinus at 500 and $50 \mu \mathrm{M}$ D-ribose. Samples were taken alternately over about $20 \mathrm{~min}$ of (i) the supernatant fluid after centrifugation and (ii) the yeast after filtration and washing.

Counting was done with an Intertechnique SL 30 liquid scintillation spectrometer for at 

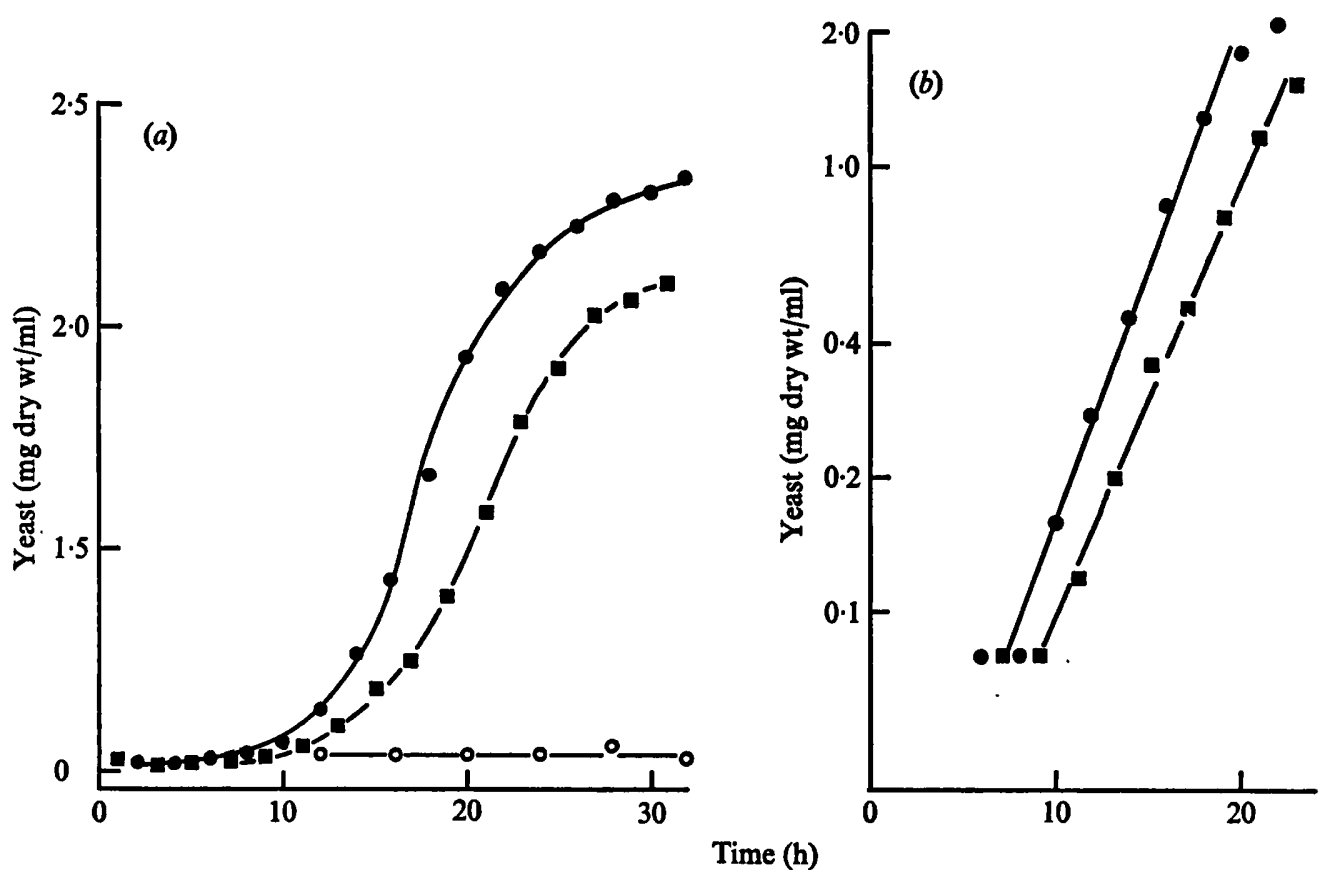

Fig. I. Time-course for growth of $P$. etchellsii (CBS2011) on D-glucose or ribitol. (a) Direct plot; (b) semi-logarithmic plot. T-tubes contained initially $15 \mathrm{ml}$ of $\mathrm{N}$-base, $0.75 \mathrm{mmol}$ of substrate (as indicated) and about $10 \mu \mathrm{g}$ dry wt of yeast from a I-day-old YM slope. The T-tubes were rocked and incubated at $25^{\circ} \mathrm{C}$ and growth was measured hourly with a recording nephelometer.

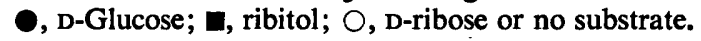

least $10^{4}$ counts or for $100 \mathrm{~min}$. The d.p.m. were calculated from the c.p.m. by a channel ratio method (Glass, 1970). The efficiency of counting was about $93 \%$.

\section{RESULTS}

\section{Growth rates}

Rates of aerobic growth, on D-ribose or ribitol, of each strain during the exponential phase are given in Table $\mathrm{I}$, where they are compared with the results of a taxonomist's qualitative assessment of growth. When growth occurred, the specific growth rate was not associated with that assessment; this was not surprising, since a taxonomist's assessment of growth on different substrates is often based on observations taken over a number of days. However, there was agreement on whether or not each strain utilized D-ribose and ribitol. Growth rates on D-glucose are given for comparison. Figure I shows linear and logarithmic plots of the time course of growth of Pichia etchellsii on D-glucose or ribitol.

\section{Oxidation of $\mathrm{D}$-ribose and ribitol by suspensions of washed yeast cells}

The rates of oxidation of D-ribose, ribitol and D-glucose by four strains of yeast are shown in Table 2. Starvation lowered the endogenous rate to $<0.3 \mu \mathrm{mol} \mathrm{O} / 2 / \mathrm{mg}$ dry wt yeast $/ \mathrm{h}$. Those yeasts that grew on D-ribose or ribitol could respire them at rates comparable to that at which they oxidized D-glucose.

Pichia fermentans did not grow on D-ribose or ribitol (Table I). Nor did it respire them, 
Table 2. Rates of respiration on D-ribose, ribitol or D-glucose as substrates by intact cells of four yeasts of the genus Pichia

\begin{abstract}
Manometer flasks contained about $4 \mathrm{mg}$ dry wt of washed, starved yeast in $2 \mathrm{ml}$ of $\mathrm{O} \cdot \mathrm{I} \mathrm{M}-\mathrm{KH}_{2} \mathrm{PO}_{4}$ in the main compartments; $20 \mu \mathrm{mol}$ of substrate (as indicated) in $0.2 \mathrm{ml}$ of water in the side arms; $0.2 \mathrm{ml}$ of $2 \mathrm{M}-\mathrm{KOH}$ with filter paper in each centre well. Incubation was in air at $25^{\circ} \mathrm{C}$ and substrates were added at zero time; $20 \mathrm{~h}$ cultures were used. The rates are given as $\mu \mathrm{mol} \mathrm{O}_{2}$ consumed/mg dry wt yeast $/ \mathrm{h}$, uncorrected for endogenous respiration.
\end{abstract}

\begin{tabular}{|c|c|c|c|c|}
\hline \multirow{2}{*}{$\begin{array}{l}\text { Carbon sources } \\
\text { in growth medium }\end{array}$} & \multicolumn{3}{|c|}{ Respiratory substrate } & \multirow[b]{2}{*}{ Endogenou } \\
\hline & D-Ribose & Ribitol & D-Glucose & \\
\hline \multicolumn{5}{|l|}{ P. fermentans (CBSI 87) } \\
\hline Succinate & 0.18 & 0.18 & $3 \cdot 8$ & 0.18 \\
\hline Succinate $+D$-ribose & 0.27 & 0.27 & $3 \cdot 2$ & 0.27 \\
\hline Succinate + ribitol & 0.27 & 0.27 & $3 \cdot 7$ & 0.22 \\
\hline D-Xylose & 0.09 & 0.09 & $\mathrm{I} \cdot 8$ & 0.09 \\
\hline \multicolumn{5}{|l|}{ P. etchellsii (CBS2OII) } \\
\hline Succinate & 0.22 & $\mathrm{I} \cdot 5$ & $3 \cdot 3$ & 0.13 \\
\hline Succinate + D-ribose & 0.40 & $\mathrm{I} \cdot 4$ & 2.9 & 0.22 \\
\hline Citrate & $0.3 \mathrm{I}$ & $2 \cdot I$ & $3 \cdot 5$ & 0.13 \\
\hline Citrate + D-ribose & 0.63 & $3 \cdot I$ & $4 \cdot 6$ & 0.13 \\
\hline Ribitol & 0.54 & $2 \cdot 6$ & $3 \cdot 3$ & 0.27 \\
\hline \multicolumn{5}{|l|}{ P. pinus (CBs5097) } \\
\hline Succinate & 0.33 & $I \cdot 4$ & $6 \cdot 3$ & 0.25 \\
\hline D-Ribose & 3.0 & 3.5 & $4 \cdot 2$ & 0.17 \\
\hline Ribitol & 0.29 & $3 \cdot 3$ & $2 \cdot 7$ & 0.24 \\
\hline \multicolumn{5}{|l|}{$P$. trehalophila $(\mathrm{CBS} 536 \mathrm{I})$} \\
\hline Succinate & 0.32 & 0.80 & $4 \cdot 5$ & 0.17 \\
\hline D-Ribose & 3.5 & 0.17 & $4 \cdot I$ & 0.15 \\
\hline Ribitol & 0.25 & $3 \cdot I$ & $3 \cdot 0$ & 0.13 \\
\hline
\end{tabular}

even after growth on (i) succinate in the presence of $50 \mathrm{~mm}$ D-ribose or ribitol or (ii) D-xylose. Growth on D-xylose was tried because it induces at least two enzymes of ribose and ribitol metabolism in a strain of Candida utilis (CBS5947) which utilizes neither compound if supplied exogenously (Barnett, I968 $a, b$ ).

Pichia etchellsii grew on ribitol but not D-ribose (Table I). This yeast respired ribitol quite quickly, irrespective of the growth substrate (Table 2). Although oxygen uptake in the presence of D-ribose was low, it is striking that it was appreciably greater than the endogenous rate and, moreover, highly correlated with that for ribitol $(+0.85)$ over nine experiments.

Both Pichia pinus and $P$. trehalophila (CBS536I) grew on D-ribose and on ribitol (Table I). However, these yeasts differed in the inducibility of their utilization of these compounds. With $P$. pinus, only ribose-grown yeast respired D-ribose appreciably, whereas ribitol was respired after growth on succinate, ribose or ribitol. By contrast, $P$. trehalophila respired ribose only when ribose-grown, and respired ribitol only when ribitol-grown (Table 2).

\title{
Entry of D-ribose into yeast cells
}

Table 3 gives the results of measuring the apparent half-saturation constants and maximum velocities of D-ribose entry for $P$. pinus grown on D-ribose or succinate. Estimates of the $K_{m}$ were between 0.09 and 0.20 mM D-ribose for D-ribose-grown yeast; two estimates for succinate-grown yeast were 3.3 and $4.9 \mathrm{~mm} \mathrm{D}$-ribose.

In Fig. 2, the effect of varying concentrations of exogenous D-ribose on the rate of its uptake in $P$. pinus is compared with that in $P$. fermentans, both succinate-grown. The 
Table 3. Measurements of apparent kinetic constants of D-ribose entry into cells of Pichia pinus (CBS5097)

\begin{tabular}{|c|c|c|c|c|}
\hline Yeast grown on & Preparation & Method of measurement & $\begin{array}{l}\text { Half-saturation } \\
\text { constant, } K_{m} \\
\text { (mM-D-ribose) }\end{array}$ & $\begin{array}{c}\text { Maximum velocity, } \\
v_{\max } \text { (nmol D-ribose } / \\
\min / \text { mg dry wt } \\
\text { yeast) }\end{array}$ \\
\hline D-Ribose & Starved, resting & Net uptake by yeast & $\left\{\begin{array}{l}0.2 \\
0.11\end{array}\right.$ & $\begin{array}{l}40 \\
43\end{array}$ \\
\hline D-Ribose & $\begin{array}{l}\text { Exponentially } \\
\text { growing }\end{array}$ & Net uptake by yeast & 0.11 & 27 \\
\hline D-Ribose & $\begin{array}{l}\text { Exponentially } \\
\text { growing }\end{array}$ & $\begin{array}{l}\text { Disappearance from } \\
\text { medium }\end{array}$ & $\left\{\begin{array}{l}0.11 \\
0.09\end{array}\right.$ & $\begin{array}{l}56 \\
40\end{array}$ \\
\hline Succinate & Starved, resting & Net uptake by yeast & $\left\{\begin{array}{l}4 \cdot 9 \\
3 \cdot 3\end{array}\right.$ & $\begin{array}{l}14 \\
39\end{array}$ \\
\hline
\end{tabular}
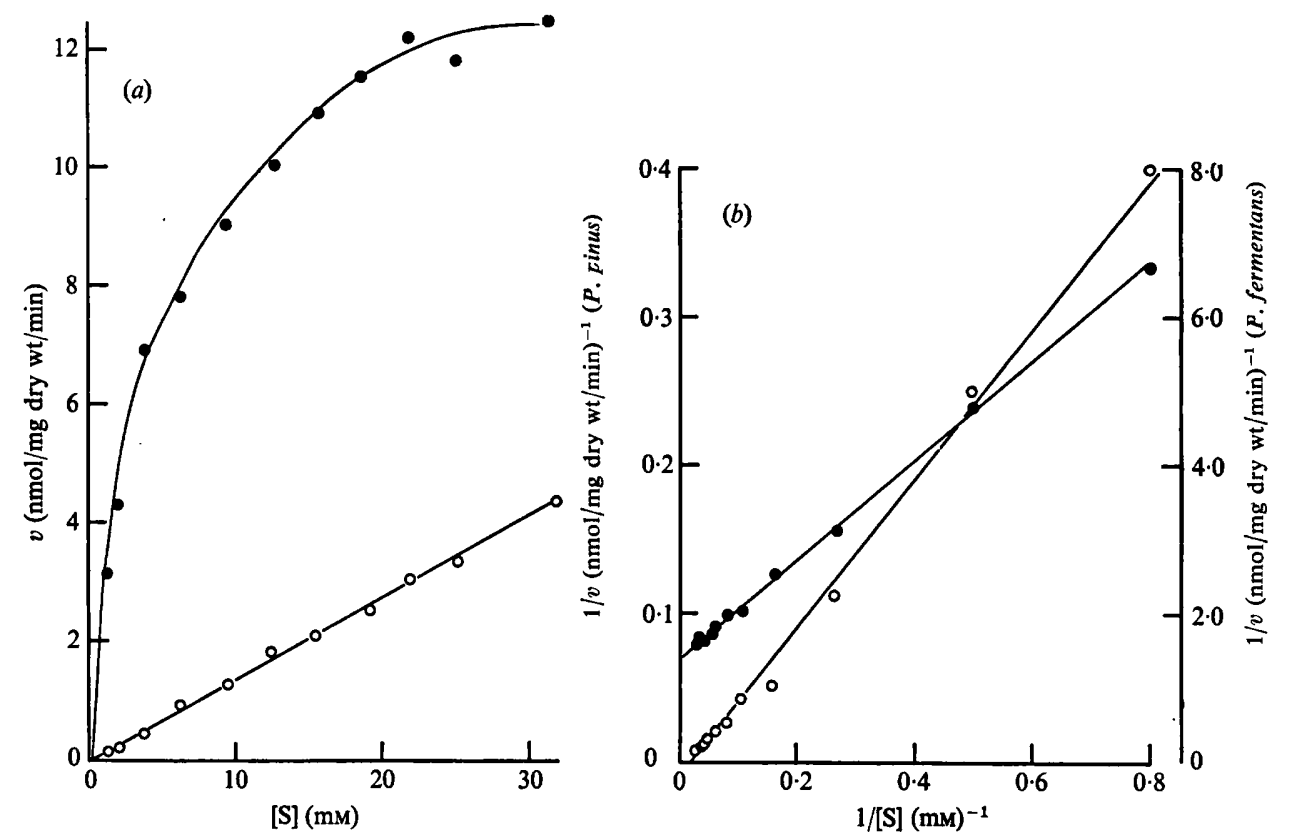

Fig. 2. D-Ribose uptake at different concentrations of D-ribose by two succinate-grown yeasts. Incubations were in $0.1 \mathrm{M}-\mathrm{KH}_{2} \mathrm{PO}_{4}$ at $30^{\circ} \mathrm{C}$. (a) Direct (Michaelis-Menten) plots; (b) reciprocal (Lineweaver-Burk) plots. $\bullet, P$. pinus; $\bigcirc, P$. fermentans.

relationship for $P$. pinus shows typical saturation kinetics, whilst that for $P$. fermentans appears to be linear with respect to substrate concentration, at least up to about $32 \mathrm{~mm}$ D-ribose. Figure 3 compares reciprocal plots of D-ribose transport by D-ribose-grown $P$. pinus, measured (i) by increase in radioactivity in cells which were collected on membranefilters or (ii) by disappearance of radioactivity from the suspending medium. For two concentrations of exogenous D-ribose, Fig. 4 compares the results of the two methods, namely loss from the medium and net uptake by the yeast. The ratio of net uptake to loss from the medium was $0.6 \mathrm{I}$ for $2.5 \mathrm{mM}$ and 0.60 for $0.25 \mathrm{~mm}$ D-ribose.

The effect of change in temperature on the rate of entry of D-ribose into both yeasts is shown as an Arrhenius plot in Fig. 5. With P. fermentans the plot is linear between 15 and 


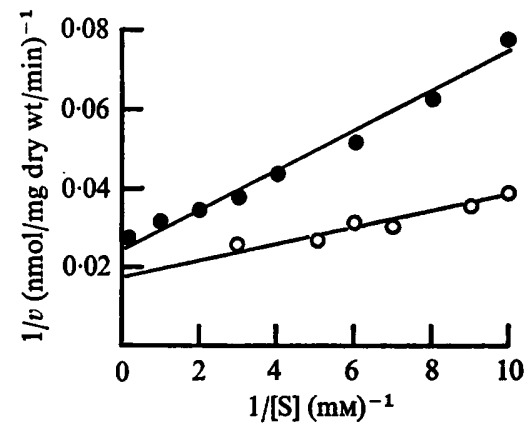

Fig. 3. Reciprocal (Lineweaver-Burk) plots of D-ribose uptake by D-ribose-grown P. pinus (CBS5097) at different concentrations of D-ribose. Measurements were made of $(\bullet)$ net uptake into starved yeast, and $(O)$ loss from the suspending medium into exponentially-growing yeast.
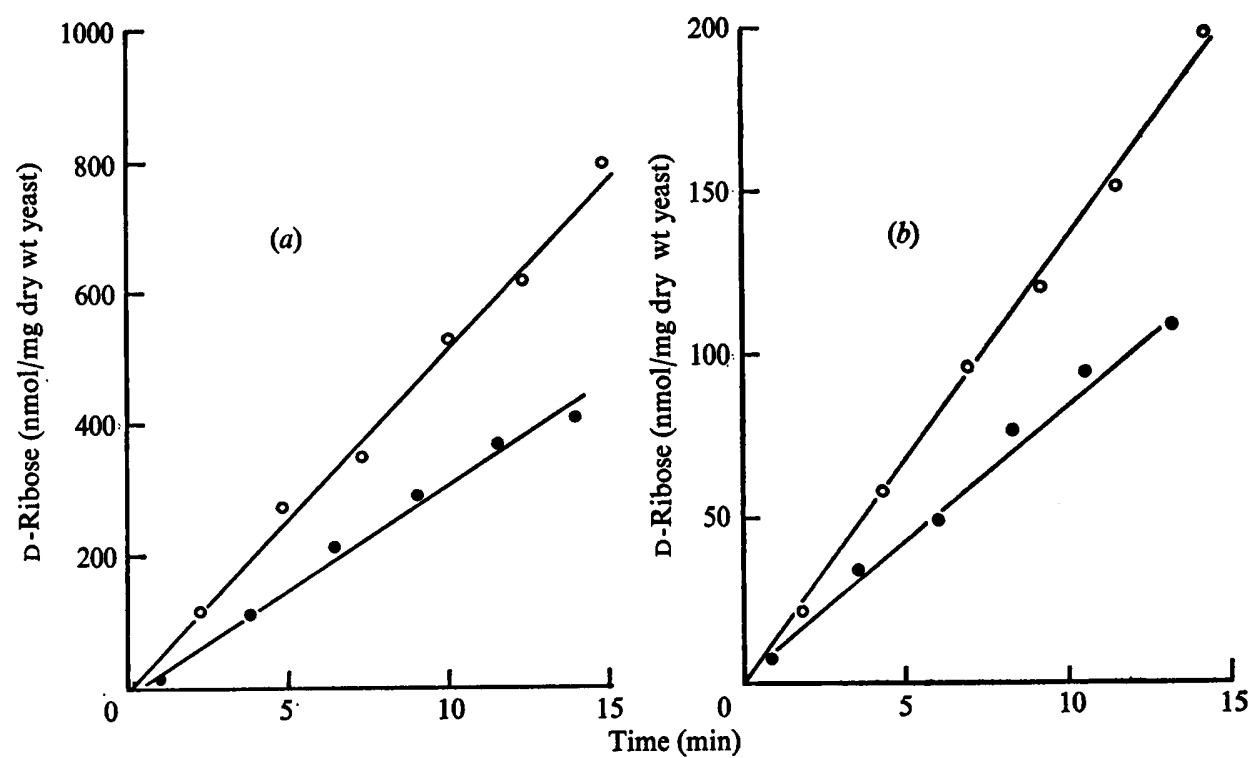

Fig. 4. Net uptake by yeast $(O)$ and loss from the suspending medium $(O)$ of D-ribose for D-ribosegrown $P$. pinus (CBS5097), with initial exogenous concentrations of D-ribose of (a) $2.5 \mathrm{mM}$, and (b) $0.25 \mathrm{mM}$.

$35^{\circ} \mathrm{C}$, whereas that for $P$. pinus may be interpreted as showing a 'break' (cf. Kumamoto, Raison \& Lyons, I97I), with a maximum at between 25 and $35^{\circ} \mathrm{C}$. Heller, Winter \& Höfer (I974) obtained comparable results for D-xylose transport into Rhodosporidium toruloides (Rhodotorula gracilis). Table 4 gives the corresponding apparent energies of activation (for non-saturating conditions) and values for $Q_{10}$.

Measurements were made of the relative rates of uptake of D-ribose into succinate- and D-ribose-grown $P$. pinus, and into succinate-grown $P$. fermentans. These rates, at 0 and $30{ }^{\circ} \mathrm{C}$ and in the presence of various potential inhibitors, are given in Table 5 . The effects of these on P. fermentans are shown in Fig. 6. 


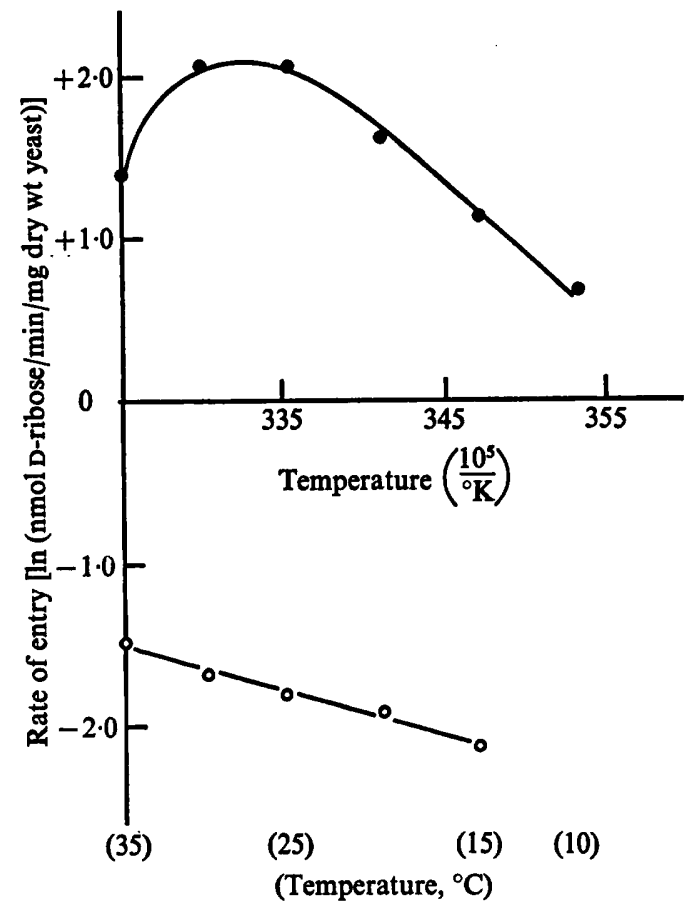

Fig. 5. Arrhenius plots showing effects of change of temperature on rate of entry of D-ribose into two succinate-grown yeasts: $O, P$. pinus CBS5097; $O, P$. fermentans CBSI87. Incubations were in $6 \mathrm{ml}$ of $0.1 \mathrm{M}-\mathrm{KH}_{2} \mathrm{PO}_{4}$. At zero time for each incubation, $20 \mu \mathrm{mol}$ of $\mathrm{D}-\left[{ }^{14} \mathrm{C}\right]$ ribose were added, and $0.5 \mathrm{ml}$ samples were taken every minute for $10 \mathrm{~min}$.

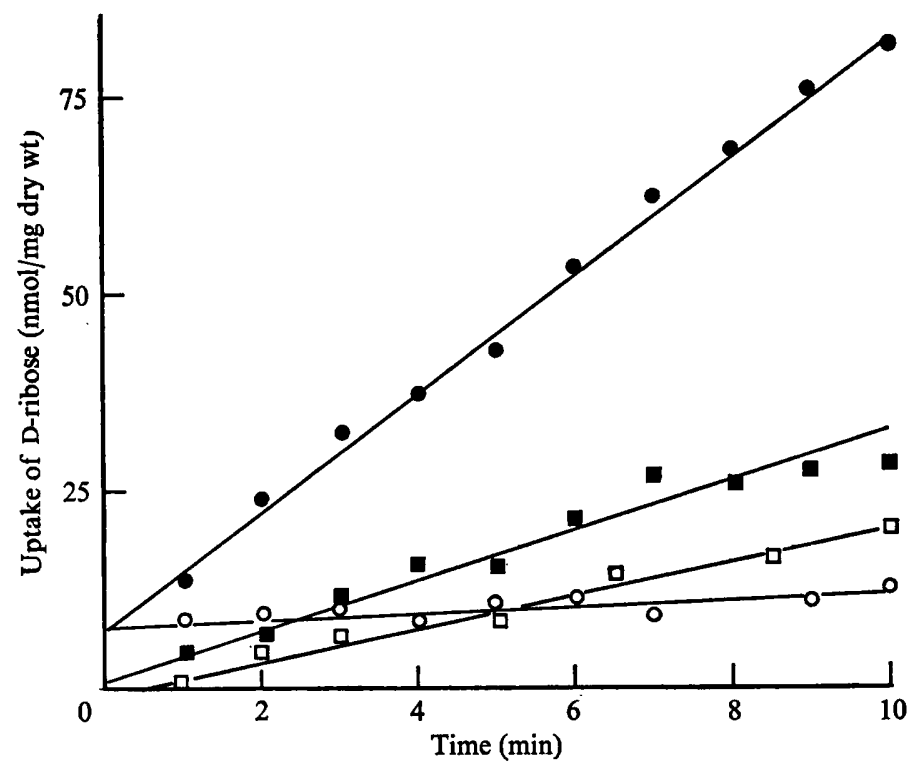

Fig. 6. Effects of inhibitors on the rates of uptake of D-ribose by succinate-grown $P$. fermentans (CBSI 87). Initial concentrations were $\mathrm{D}-\left[{ }^{14} \mathrm{C}\right]$ ribose, $\mathrm{I} \cdot 7 \mathrm{mM}$; D-glucose and 2-deoxy-D-glucose, I 7 mM; CCCP, I.O mM. O, No inhibitor; E, CCCP; $\square$, D-glucose; O, 2-deoxy-D-glucose. 
Table 4. Values for $Q_{10}$ and $E_{a}$, for entry of $25 \mathrm{mM}$ D-ribose into succinate-grown yeasts

Incubations were in $0.1 \mathrm{M}-\mathrm{KH}_{2} \mathrm{PO}_{4}$, using $25 \mathrm{ml}$ conical flasks in a shaking water bath, at various temperatures (every $5 \pm 0.2{ }^{\circ} \mathrm{C}$, from 10 to $35^{\circ} \mathrm{C}$ ).

$\begin{array}{lcc} & Q_{10} & E_{a}\left(\mathrm{~J} /{ }^{\circ} \mathrm{C} / \mathrm{mol}\right) \\ P . \text { fermentans (CBSI 87) } & 1 \cdot 5 & 2190 \\ P . \text { pinus (CBS5097) } & 2 \cdot 5 & 6590\end{array}$

Table 5. Relative rates of uptake of $\mathrm{D}-\left[{ }^{14} \mathrm{C}\right]$ ribose or $\mathrm{D}-\left[{ }^{14} \mathrm{C}\right]$ glucose in the presence of various inhibitors

Initial concentrations: $D-\left[{ }^{14} C\right]$ ribose and $D-\left[{ }^{14} C\right]$ glucose, $I \cdot 7 \mathrm{mM}$; sugars and ribitol as inhibitors, $17 \mathrm{mM}$; CCCP, I. $\mathrm{mM}$; uranyl nitrate, $25 \mu \mathrm{M}$. Absolute rate of entry of D-glucose into P. fermentans at $30^{\circ} \mathrm{C}: 18 \mathrm{nmol} \mathrm{D}-\mathrm{glucose} / \mathrm{mg}$ dry wt yeast $/ \mathrm{min}$.

\begin{tabular}{|c|c|c|c|c|c|}
\hline \multirow[b]{3}{*}{$\begin{array}{l}\text { Incubation } \\
\text { temperature }\end{array}$} & \multirow[b]{3}{*}{ Inhibitor } & \multicolumn{2}{|c|}{ P. pinus (CBS5097) } & \multirow{2}{*}{\multicolumn{2}{|c|}{$\begin{array}{l}P . \text { fermentans (CBSI 87) } \\
\text { Succinate-grown }\end{array}$}} \\
\hline & & \multirow{2}{*}{$\begin{array}{l}\text { D-Ribose- } \\
\text { grown } \\
\text { D-Ribose } \\
\text { uptake }\end{array}$} & \multirow{2}{*}{$\begin{array}{l}\text { Succinate- } \\
\text { grown } \\
\text { D-Ribose } \\
\text { uptake }\end{array}$} & & \\
\hline & & & & $\begin{array}{l}\text { D-Ribose } \\
\text { uptake }\end{array}$ & $\begin{array}{l}\text { D-Glucose } \\
\text { uptake }\end{array}$ \\
\hline $0^{\circ} \mathrm{C}$ & None & 0 & 5 & 40 & NT \\
\hline \multirow[t]{9}{*}{$30^{\circ} \mathrm{C}$} & None & 100 & 100 & 100 & 100 \\
\hline & 2-Deoxy-D-glucose & 89 & 90 & 5 & 32 \\
\hline & 2-Deoxy-D-ribose & 89 & 84 & NT & 98 \\
\hline & Ribitol & 69 & 84 & 100 & 96 \\
\hline & D-Glucose & 101 & 94 & 20 & - \\
\hline & D-Ribose & - & - & 一 & 98 \\
\hline & $\mathrm{CCCP}$ & $\mathbf{I}$ & $\mathbf{N T}$ & 40 & 18 \\
\hline & Uranyl nitrate & 100 & NT & NT & NT \\
\hline & & \multicolumn{2}{|c|}{ NT, Not tested. } & & \\
\hline
\end{tabular}

\section{DISCUSSION}

Neither $P$. fermentans nor $P$. etchellsii utilized D-ribose for aerobic growth, though the sugar appeared to enter their cells. The results of studying the entry of D-ribose into $P$. fermentans are open to alternative interpretations.

(i) Since over a wide range of concentrations, the rate of uptake of exogenous ribose was directly proportional to the external concentrations of the sugar (Fig. 2a), entry could occur by simple diffusion. This explanation was given by Herzenberg (1959) for his analogous results with cryptic mutants of Escherichia coli with respect to their uptake of $o$-nitrophenyl $\beta$-D-galactopyranoside. The effects of change of temperature on entry (Fig. 5), with a low $Q_{10}(\mathrm{I} \cdot 5)$ and an apparent activation energy $\left(E_{a}\right)$ of $2190 \mathrm{~J} /{ }^{\circ} \mathrm{C} / \mathrm{mol}$ (Table 4 ), are also consistent with entry by simple diffusion (cf. Stein, 1967). This is how Horák \& Kotyk (1969) interpreted the results of their experiments on the uptake of D-ribose by a strain of $R$ hodosporidium toruloides (Rhodotorula gracilis). However, there were some indications from their results (e.g. the effect of 2,4-dinitrophenol on uptake) that this process might not be fully explicable in terms of simple diffusion.

(ii) An alternative interpretation of the apparently linear plot for P. fermentans in Fig. $2(a)$, as well as for the results with $R$. toruloides (Horák \& Kotyk, 1969), is that this line could correspond to the lower part of a rectangular hyperbola, representing the activity of a carrier-mediated system with a very low affinity for D-ribose, although this view is not 
borne out by the reciprocal plot in Fig. $2(b)$. Accordingly, in view of the obvious possibility that D-ribose might enter by means of a constitutive carrier with a high affinity for another sugar, some experiments were done on the transport of D-glucose, for comparison. Indeed, the effects of various inhibitors on the rate of entry into $P$. fermentans of D-ribose, on the one hand, and of D-glucose on the other (Table 5), were consistent with the suggestion that ribose entered by means of the glucose carrier. This conclusion accords with the findings of Heredia, Sols \& Delafuente (I968) for Saccharomyces cerevisiae with respect to D-ribose and a number of non-metabolizable sugars (for review, see Barnett, 1975).

Table 5 compares the effects of certain possible inhibitors on the uptake of D-ribose by $P$. pinus and $P$. fermentans, as well as of D-glucose by succinate-grown $P$. fermentans. With $P$. pinus, D-glucose hardly affected D-ribose uptake, so the two sugars probably enter by different carriers. Furthermore, uptake was unaffected by uranyl ions, which are fast-acting inhibitors of sugar uptake by yeasts, including facilitated diffusion (Rothstein, 1954; Cirillo, I96 I $a, b$ ). CCCP uncouples oxidative phosphorylation, inhibiting active transport of sugars in some bacteria (for review, see Cirillo, 1972); therefore its inhibition of uptake (almost total for $P$. pinus and partial for $P$. fermentans) suggests that metabolic energy is involved in the uptake of D-ribose by both yeasts. The action of ribitol in inhibiting uptake by $P$. pinus might at least partly be due to it affecting the metabolism of D-ribose. However, should this action prove instead to be competitive inhibition of transport, it will be pertinent to ask in what molecular form D-ribose crosses the plasmalemma of $P$. pinus. Since ribitol is acyclic, possibly it is aldehydo-D-ribose that enters (Barnett, 1975). The effect of the inhibitors on $P$. fermentans was immediate (Fig. 6), so they could have acted directly on the carrier of D-ribose. The action of inhibitors on the uptake of D-ribose by $P$. fermentans, and the similarity of this action to that on uptake of D-glucose, are evidence that carrier-mediated uptake of D-ribose occurs in this yeast by means of a D-glucose carrier.

Since D-ribose was catabolized by $P$. pinus, experiments were done to find out whether the measurements of kinetic constants of uptake were confuted by variations in the proportion of ${ }^{14} \mathrm{C}$ lost as $\mathrm{CO}_{2}$. Accordingly, D-ribose-grown yeast was studied, because it utilized D-ribose fastest and so would be most likely to give the highest variations. However, the different estimates of $K_{m}$ were similar (90 to $200 \mu \mathrm{M}$, Table 3), whether based on measurements of net uptake of D-ribose or on its disappearance from the medium. Furthermore, the ratios of the rates of loss from the medium to those of net uptake by the yeast (Fig. 4) were similar for exogenous concentrations of 50 and $500 \mu \mathrm{M}$ D-ribose. Hence the results of the present experiments on the kinetics of D-ribose uptake were probably not invalidated by changes in the proportion of sugar metabolized when its exogenous concentration was varied. On the other hand this might possibly be true for differences associated with changes in temperature, measured with succinate-grown $P$. pinus.

Unlike $P$. fermentans, $P$. etchellsii utilizes ribitol for growth, though not D-ribose (Kreger-van Rij, 1970; and see Table I). In addition, Table 2 shows that $P$. etchellsii respires D-ribose slowly, and that this rate of respiration by cells grown on citrate in the presence of $\mathrm{D}$-ribose is double that for those grown on citrate alone. This combination of characteristics - ability to grow on and respire ribitol, and inability to grow on but ability to respire D-ribose - cannot be explained simply in terms of conventional concepts of ribose and ribitol catabolism (for review, see Barnett, I968a, 1975):

or

$$
\begin{aligned}
\text { D-ribose } \rightarrow & \text { ribitol } \rightarrow \text { D-erythro-pentulose } \rightarrow \text { D-erythro-pentulose 5-phosphate } \rightarrow \\
& \text { D-threo-pentulose 5-phosphate } \rightarrow \text { pentose cycle reactions }
\end{aligned}
$$

D-ribose $\rightarrow$ D-ribose 5-phosphate $\rightarrow$ D-erythro-pentulose 5-phosphate, etc. 
Haškovec \& Kotyk (1973) reported an identical observation on Torulopsis candida, but Barnett ( $1968 b$ ) found that the same strain would grow on ribose. Pichia etchellsii is being investigated further.

The estimates of $E_{a}$ for D-ribose entry into succinate-grown yeast were higher for $P$. pinus than for $P$. fermentans (Table 4). These observations are consistent with the view that for $P$. pinus the rate-determining step of entry involved binding or release. The different values for $K_{m}$ and $v_{\max }$ with succinate- and D-ribose-grown $P$. pinus (Table 3 ) are evidence of there being two carriers (or sites) for D-ribose entry, one of them inducible. The non-induced carrier in $P$. pinus differs markedly from that of $P$. fermentans, in -exhibiting saturationkinetics (Fig. 2), in its temperature relations (Fig. 5 and Table 4) and in its reactions to inhibitors (Table 5).

Ribitol never clearly induced the utilization of D-ribose (Table 2), though $P$. etchellsii may have been an exception. In $P$. pinus, ribitol induced the respiration of ribitol, and ribose induced both ribose and ribitol utilization, whereas in $P$. trehalophila, ribose utilization was induced only in D-ribose-grown yeast and ribitol respiration only in ribitol-grown yeast.

I am much indebted to Professor B. F. Folkes for his kindly interest and encouragement, to various colleagues, particularly Dr A. P. Sims and Dr P. C. Croghan, for many valuable suggestions and criticisms, and to Miss V. Box for measurements of numbers of cells.

\section{REFERENCES}

BARnett, J. A. (1968a). Biochemical differentiation of taxa. In The Fungi, An Advanced Treatise, vol. 3, pp. 557-595. Edited by G. C. Ainsworth and A. S. Sussman. New York and London: Academic Press.

BarNetT, J. A. (1968b). The catabolism of acyclic polyols by yeasts. Journal of General Microbiology 52, I3I-I59.

BARNETt, J. A. (1975). The utilization of sugars by yeasts. Advances in Carbohydrate Chemistry and Biochemistry 32 (in the Press).

BarnetT, J. A. \& INGRAM, M. (1955). Technique in the study of yeast assimilation reactions. Journal of Applied Bacteriology 18, 13 I-148.

Cirillo, V. P. (I96I $a$ ). The mechanism of sugar transport into the yeast cell. Transactions of the New York Academy of Sciences 23, 725-734.

Cirillo, V. P. (196I b). Sugar transport in microorganisms. Annual Review of Microbiology 15, 197-218.

Cirillo, V. P. (1972). Inhibition of transport reactions. In Metabolic Inhibitors, A Comprehensive Treatise, vol. 3, pp. 47-68. Edited by R. M. Hochster, M. Kates and J. H. Quastel. New York and London: Academic Press.

GLASs, D. S. (1970). Automatic quench correction by channels ratio for both carbon-I4 and tritium using a three channel liquid scintillation counter. International Journal of Applied Radiation and Isotopes 2r, $53 \mathrm{I}-544$.

HAŠKovec, C. \& KoTYK, A. (1973). Transport systems for acyclic polyols and monosaccharides in Torulopsis candida. Folia microbiologica (Praha) 18, $118-124$.

HeLleR, K. B., WinTER, U. \& HöFER, M. (I974). Temperature dependence of the membrane permeability in Rhodotorula gracilis. In Proceedings of the Fourth International Symposium on Yeasts, Vienna, Part $\mathrm{I}$, pp. 285-286.

Heredia, C. F., Sols, A. \& Delafuente, G. (1968). Specificity of the constitutive hexose transport in yeast. European Journal of Biochemistry 5, 321-329.

HERZENBERG, L. A. (I959). Studies on the induction of $\beta$-galactosidase in a cryptic strain of Escherichia coli. Biochimica et biophysica acta 31, 525-538.

HoRÁK, J. \& KOTYK, A. (1969). Anomalous uptake of D-ribose by Rhodotorula gracilis. Folia microbiologica (Praha) 14, 29I-296.

KotyK, A. \& JANÁČEK, K. (1970). Cell Membrane Transport, pp. 21 I-213. New York: Plenum Press. 
Kreger-VAn RiJ, N. J. W. (1964). A taxonomic study of the yeast genera Endomycopsis, Pichia and Debaryomyces. Thesis, University of Leiden.

Kreger-van RIJ, N. J. W. (1970). Pichia Hansen. In The Yeasts. A Taxonomic Study, pp. 455-554. Edited by by J. Lodder. Amsterdam: North-Holland Publishing.

Kumamoto, J., Raison, J. K. \& Lyons, J. M. (1971). Temperature 'breaks' in Arrhenius plots: a thermodynamic consequence of a phase change. Journal of Theoretical Biology 31, 47-5I.

RothSTEIN, A. (1954). Enzyme systems of the cell surface involved in the uptake of sugars by yeast. Symposia of the Society for Experimental Biology 8, 165-201.

Stein, W. D. (1967). The Movement of Molecules across Cell Membranes, p. 71. New York: Academic Press. VAN DER WALT, J. P. (1970). Wingea v.d. Walt. In The Yeasts. A Taxonomic Study, pp. 772-775. Edited by J. Lodder. Amsterdam: North-Holland Publishing.

Whistler, R. L. \& Bemiller, J. N. (1962). Purification of commercial D-ribose through its 'anilide'. In Methods in Carbohydrate Chemistry, vol. I, pp. 8I-82. Edited by R. L. Whistler and M. L. Wolfrom. New York: Academic Press.

WiCKerham, L. J. \& BURTON, K. A. (1948). Carbon assimilation tests for the classification of yeasts. Journal of Bacteriology 56, 363-371. 